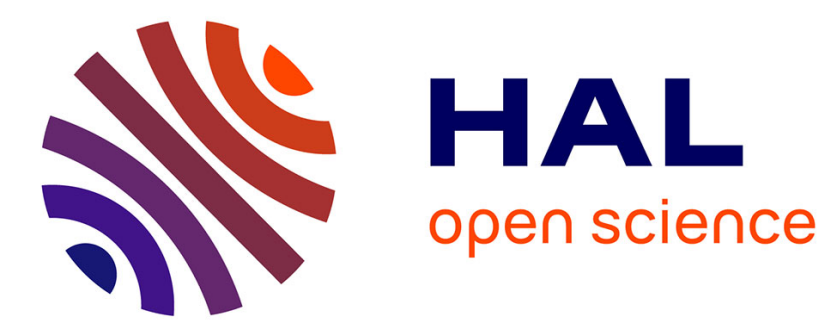

\title{
XPS Analysis of K-based Reference Compounds to Allow Reliable Studies of Solid Electrolyte Interphase in K-ion Batteries
}

\author{
Laure Caracciolo, Lénaïc Madec, Hervé Martinez
}

\section{- To cite this version: \\ Laure Caracciolo, Lénaïc Madec, Hervé Martinez. XPS Analysis of K-based Reference Compounds to Allow Reliable Studies of Solid Electrolyte Interphase in K-ion Batteries. ACS Applied Energy Materials, 2021, 4 (10), pp.11693-11699. 10.1021/acsaem.1c02400 . hal-03409209}

\author{
HAL Id: hal-03409209 \\ https://hal.science/hal-03409209
}

Submitted on 29 Oct 2021

HAL is a multi-disciplinary open access archive for the deposit and dissemination of scientific research documents, whether they are published or not. The documents may come from teaching and research institutions in France or abroad, or from public or private research centers.
L'archive ouverte pluridisciplinaire HAL, est destinée au dépôt et à la diffusion de documents scientifiques de niveau recherche, publiés ou non, émanant des établissements d'enseignement et de recherche français ou étrangers, des laboratoires publics ou privés. 


\title{
XPS analysis of K-based reference compounds to allow reliable stud- ies of solid electrolyte interphase in $\mathrm{K}$-ion batteries.
}

\author{
Laure Caracciolo, Lénaïc Madec, ${ }^{*}$ Hervé Martinez*
}

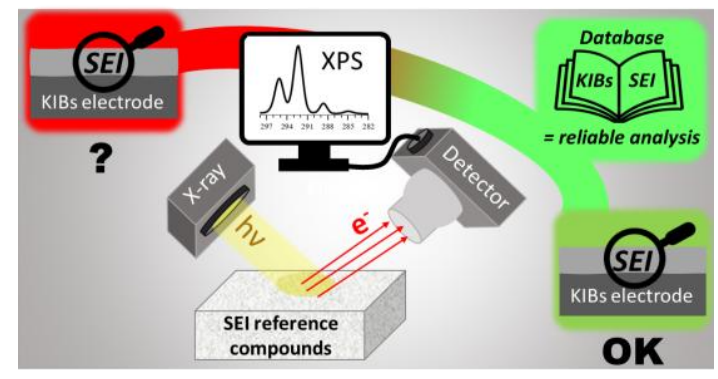

\begin{abstract}
As for Li- and Na-ion batteries, the electrolyte reactivity (i.e. the salts and solvents decomposition) also plays a crucial role on the electrochemical performance of K-ion batteries (KIBs). However, X-ray photoelectron spectroscopy (XPS) analysis of the solid electrolyte interphase (SEI) in KIBs remains based on Li-ion and Na-ion literature so far. This may lead to incorrect interpretations of the results considering that the first ionisation potential difference between the alkali metals is expected to significantly change the binding energy values observed by XPS for a given M-based (M=Li, Na or K) compound. Therefore, this work aims at providing XPS characterization of numerous commercial K-based reference compounds, including some that were still missing in the literature. In particular, absolute and relative binding energy values are given and compared to corresponding Li and Na counterparts. This work will thus help researchers to get reliable XPS analysis of the SEI in KIBs.
\end{abstract}

\section{KEYWORDS}

K-ion batteries, solid electrolyte interphase, XPS, K-based reference compounds, binding energy values.

\section{INTRODUCTION}

$\mathrm{K}$-ion batteries appear as a promising alternative for largescale energy storage systems for which abundant and low-cost raw materials are required. Indeed, with the lowest (i) redox couple potential, (ii) Lewis acidity and (iii) desolvation energy among alkali metals in non-aqueous carbonate electrolytes, potassium can enable high voltage and high power $\mathrm{KIBs}^{1-3}$. Recent studies, focused on negative and positive electrode materials, showed that promising electrochemical performance can be obtained with graphite that reversibly intercalates $\mathrm{K}^{+}$ into $\mathrm{KC}_{8}$ and Prussian blue analogue or phosphates materials such as $\mathrm{KVPO}_{4} \mathrm{~F}^{4-9}$.

However, studies on the SEI remain rare so far, even though electrolyte formulation and SEI formation were clearly found critical to KIBs successful operation ${ }^{2}$. SEI formation is the result of electrolyte salt(s) and solvent(s) degradation at the electrodes surface during cycling and/or storage. For instance, in half-cells, $\mathrm{K}$ metal leads to the formation of electrolyte degradation species that migrate to the working electrode surface (called cross-talk or interaction ${ }^{10}$ between electrode), which makes SEI's half-cell studies not reliable. ${ }^{11,12}$ Thus, full cell are key studies for reliable SEI analysis in KIBs.

X-Ray Photoelectron Spectroscopy (XPS) analysis is probably the most frequently used technique to obtain the chemical
SEI composition. It is performed by core-level binding energies assignment based on literature reference compounds database. However, despite numerous studied on $\mathrm{Li}^{3}{ }^{3,10}$ and Na-based ${ }^{12,14}$ reference compounds, data on corresponding Kbased counterparts are still missing in the literature. Thus, considering that the first ionisation potential difference between alkali metals is expected to significantly change the binding energy values observed by XPS for a given M-based $(\mathrm{M}=\mathrm{Li}, \mathrm{Na}$ or $\mathrm{K})$ compounds. In other words, as the first ionization potential decreases from $\mathrm{Li}$ to $\mathrm{K}$, a higher delocalisation of valence electron density (i.e. screening effect increase) is expected from the $\mathrm{M}$ atom to the $\mathrm{O}$ or $\mathrm{F}$ atom for an $\mathrm{M}-\mathrm{F}$ or $\mathrm{M}-\mathrm{O}$ chemical bond, as illustrated in Figure 5. Therefore, SEI study in KIBs based on $\mathrm{Li}$ - and Na-based reference compounds can not be reliable. Moreover, it is well known that binding energy values for reference compounds depend on the calibration method used. Generally, it is based on the C-C, C$\mathrm{H}$ carbon peak at $285.0 \mathrm{eV}$, attributed to contamination. However, both calibration (that may differ between studies) and differential charging effects (due to insulating sample properties) may lead to different binding energy values between studies. As an alternative, valence band spectra (0-35 eV) can be used as a fingerprint to identify a specific compound as proposed in $\mathrm{Li}^{-}$and Na-based SEI. ${ }^{13-15}$ However, this approach is not appropriate for SEI containing numerous compounds and/or for SEI containing an element for which the effective photoionization cross-sections are much higher than those of the other characteristic elements resulting in high intensity peak(s) in the valence band region, such as potassium (i.e. with orbitals $3 \mathrm{~s}$ and $3 \mathrm{p}$ at $34 \mathrm{eV}$ and $18 \mathrm{eV}$, respectively). $12,16,17$ 
To tackle the issues raised above, this work aims at providing absolute and relative binding energy values of commercial K-based reference compounds to allow reliable XPS analysis of the SEI in KIBs. A comparison with corresponding $\mathrm{Li}$ and $\mathrm{Na}$ counterparts is also provided for better clarity.

\section{EXPERIMENTAL SECTION}

The list of the reference powder samples analyzed in this study is reported in Table S1 with the supplier name and purity grade. As received reference powders were grinded in an agate mortar for 3 min under Ar atmosphere, deposited on an XPS sample holder adapted for powder analysis (no tape was used), then transferred in a sealed box to an Ar filled glove box connected to the spectrometer. Note that no $\mathrm{Ar}^{+}$ etching was used to clean the samples surface as it can lead to sample degradation. For instance, $\mathrm{MF}$ and $\mathrm{M}_{2} \mathrm{O}$ formation were observed (not shown) for $\mathrm{MPF}_{6}$ and $\mathrm{ROM}$ sample $(\mathrm{M}=$ $\mathrm{Li}, \mathrm{Na}$ or K), respectively. XPS analysis was performed using an Escalab $250 \mathrm{Xi}$, with a monochromatized $\mathrm{Al} \mathrm{K} \alpha$ radiation $(\mathrm{h} v=1486.6 \mathrm{eV})$. The standard charge compensation mode was the same for each sample. Core spectra were recorded with a $0.15 \mathrm{eV}$ step, a constant $20 \mathrm{eV}$ pass energy and short time iteration to follow any possible sample degradation. The reproducibility was confirmed by doing three measurements for each sample, leading to binding energy values with an average deviation of $\pm 0.1 \mathrm{eV}$ for all samples. Using CasaXPS software, the binding energy scale was calibrated from the $\mathrm{C}$ $\mathrm{C}, \mathrm{C}-\mathrm{H}$ peak at $285.0 \mathrm{eV}$. Except for - $\mathrm{CHx}$ containing compounds, this peak originates from carbon contamination, which was relatively low $(<5 \%)$ due to the caution taken during sample preparation. Depending on the spectra shape, a linear or a non-linear Shirley-type background was used. 70\% Gaussian - 30\% Lorentzian Voigt peak shapes and full width at half-maximum constraint ranges were selected to optimize areas and peak positions. XPS quantification was performed using the relative sensitivity factor provided with the Escalab machine and quantification values were consistent with the stoichiometry of each compound (Table S2). 


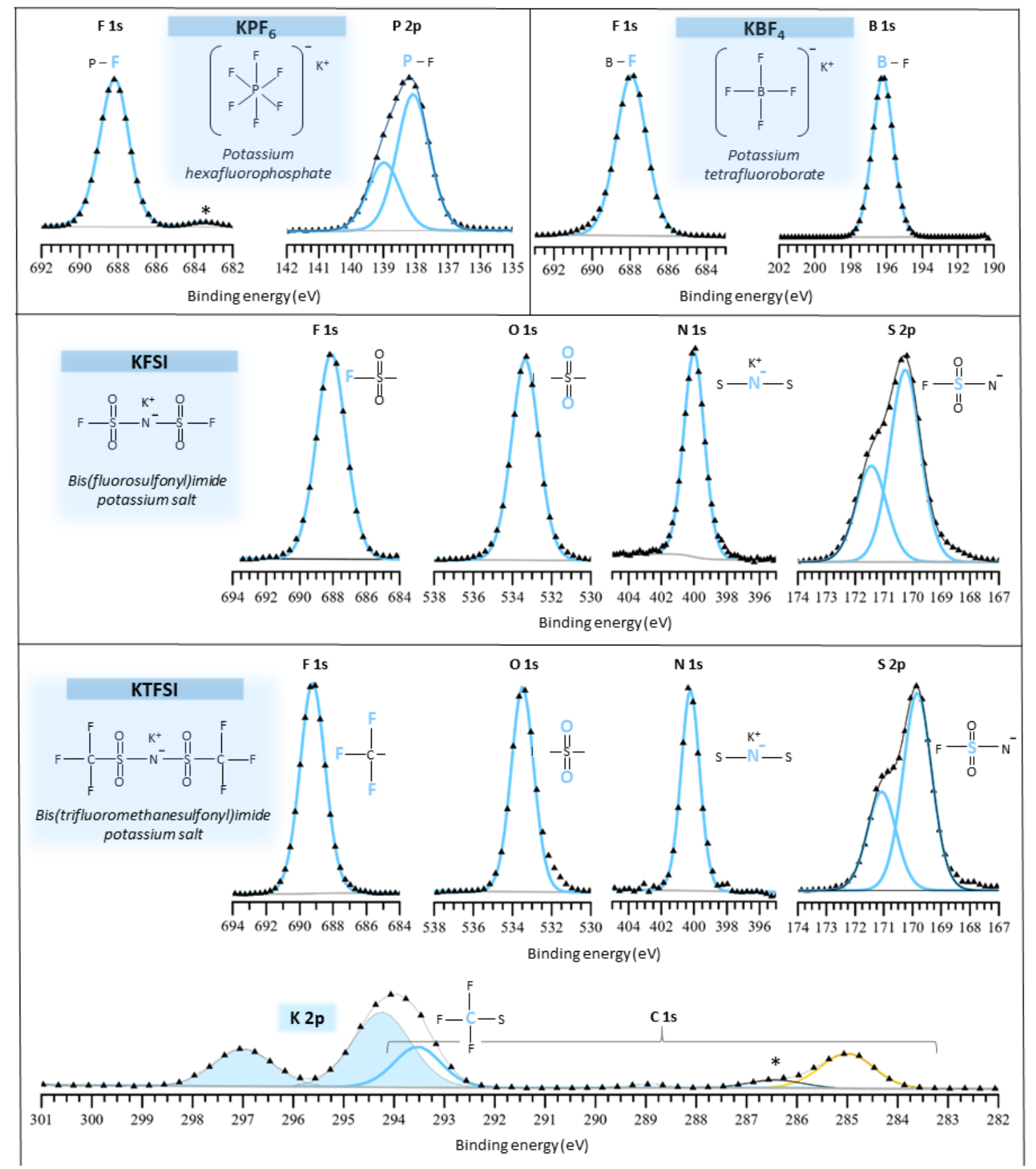

Figure 1. XPS core level spectra for the $\mathrm{KPF}_{6}$ (top left), $\mathrm{KBF}_{4}$ (top right), KFSI (middle) and KTFSI (bottom) electrolyte salts. Abscissa

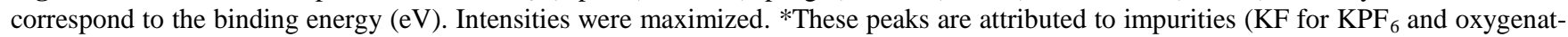

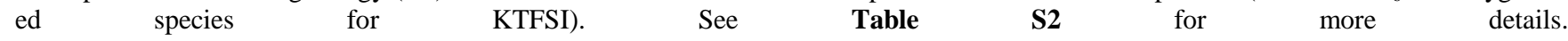

\section{RESULTS AND DISCUSSION}

Electrolyte salt reference compounds. Figure 1 shows XPS core spectra obtained for commonly used electrolyte salts, $\mathrm{KPF}_{6}, \mathrm{KBF}_{4}, \mathrm{KFSI}$, and KTFSI. Note that as expected for these K-based electrolyte salts and in agreement with Liand Na-based counterparts (Figure S1), no alkali environment impact (i.e. binding energy shift) was observed on the B 1s, N $1 \mathrm{~s}$, and $\mathrm{P} 2 \mathrm{p}$ peaks due to the delocalized charge of the anions ${ }^{18}$.
F 1s XPS core spectra of $\mathrm{KPF}_{6}$ showed a peak at 688.2 $\pm 0.1 \mathrm{eV}$ attributed to $-\mathrm{F}_{6}$ groups while the corresponding $\mathrm{P} 2 \mathrm{p}$ peak was observed at $138.1 \pm 0.1 \mathrm{eV} . \mathrm{KBF}_{4} \mathrm{XPS}$ core spectra showed a $F 1$ s peak at $688.0 \pm 0.1 \mathrm{eV}$ and a B 1 s peak at 196.2 $\pm 0.1 \mathrm{eV}$, in agreement with the literature ${ }^{19}$. S 2p XPS core spectra of KFSI showed a peak at $170.3 \pm 0.1$ attributed to $\mathrm{NSO}_{2} \mathrm{~F}$ environment while the corresponding $\mathrm{N} 1 \mathrm{~s}, \mathrm{O} 1 \mathrm{~s}$ and $\mathrm{F}$ $1 \mathrm{~s}$ peaks were observed at $400.0 \pm 0.1 \mathrm{eV}, 533.4 \pm 0.1 \mathrm{eV}$ and $688.1 \pm 0.1 \mathrm{eV}$, respectively. For KTFSI, the $\mathrm{O} 1 \mathrm{~s}, \mathrm{~N} 1 \mathrm{~s}$ and $\mathrm{S}$ $2 \mathrm{p}$ XPS core spectra showed peaks, attributed to $\mathrm{NSO}_{2}$ environment, at $533.4 \pm 0.1 \mathrm{eV}, 400.2 \pm 0.1 \mathrm{eV}$ and $169.8 \pm 0.1 \mathrm{eV}$, 
respectively. The F 1s XPS core spectra showed a major peak at $689.2 \pm 0.1 \mathrm{eV}$, attributed to $-\mathrm{CF}_{3}$ from KTFSI. The corresponding $\mathrm{C} 1 \mathrm{~s}$ peak from $-\mathrm{CF}_{3}$ was observed at $293.5 \pm 0.1 \mathrm{eV}$. Note that for KTFSI, the $\mathrm{K} 2 \mathrm{p}_{3 / 2}$ peak from the $\mathrm{K} 2 \mathrm{p}$ doublet (blue-filled components in Figure 1) appears at $294.2 \mathrm{eV}$ so that it is only $0.7 \mathrm{eV}$ separated from the $-\mathrm{CF}_{3}$ carbon peak. It was therefore essential to first fit the $\mathrm{K} 2 \mathrm{p}$ orbital by adjusting the area ratio $\left(\mathrm{Area}_{2 \mathrm{p} 1 / 2}=0.5^{*} \mathrm{Area}_{2 \mathrm{p} 3 / 2}\right)$, imposing equal full width at half maximum (FWHM) band doublet spacing $\left(\Delta \mathrm{BE}_{2 \mathrm{p}(1 / 2-3 / 2)}=2.75 \mathrm{eV}\right)$. Second, an unconstrained $\mathrm{C} 1 \mathrm{~s}$ component was added. Note also that for the analysis of this reference compound, a single linear background for both $\mathrm{K} 2 \mathrm{p}$ and $\mathrm{C} 1 \mathrm{~s}$ regions was used but for a multi-compounds sample (i.e. for SEI analysis) it may be necessary to use a specific background for each region. To confirm the baseline accuracy, one could additionally fit the $\mathrm{K} 2 \mathrm{~s}$ orbital and check that $\mathrm{K} 2 \mathrm{p}$ and $\mathrm{K} 2$ s region leads to equal atomic percentages.

Finally, iteration monitoring during XPS core spectra acquisition showed that $\mathrm{KPF}_{6}, \mathrm{KBF}_{4}$ and KTFSI compounds were stable under the X-ray beam, while KFSI compounds suffered damages. As reported in the literature, the weak S-F bonds ${ }^{20}$

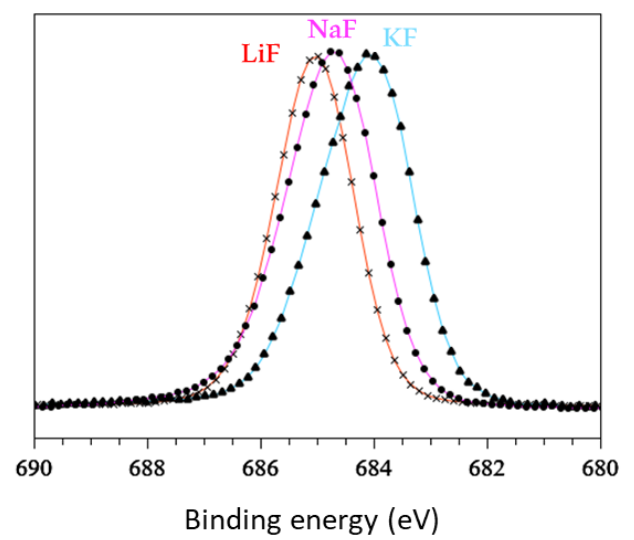

Figure 2. F 1s XPS core spectra of lithium fluoride (redcross), sodium fluoride (pink-point) and potassium fluoride (blue-triangle). Intensity were maximized for better are comparison.

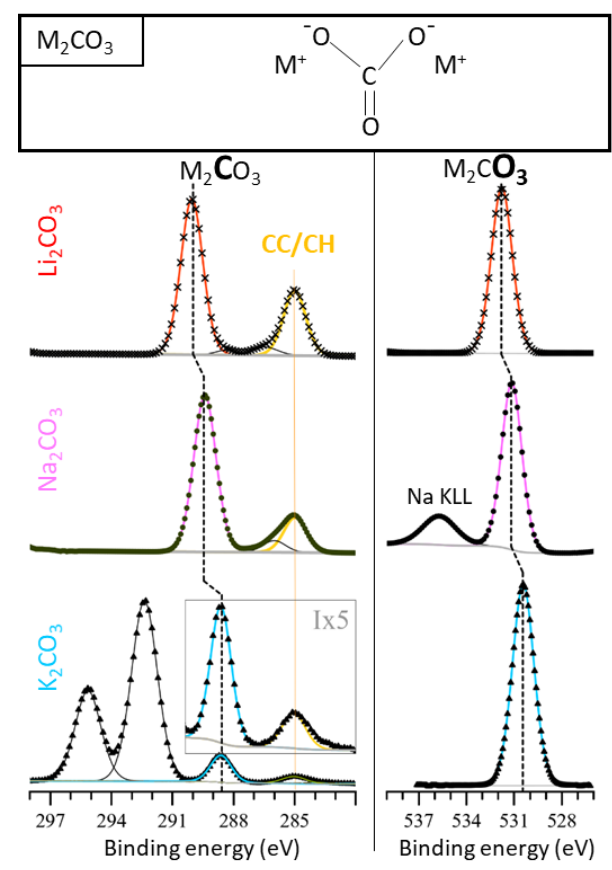

Figure 3. $\mathrm{C} 1 \mathrm{~s}$ (left) and $\mathrm{O} 1 \mathrm{~s}$ (right) XPS core spectra of $\mathrm{Li}_{2} \mathrm{CO}_{3}$ (red-cross), $\mathrm{Na}_{2} \mathrm{CO}_{3}$ (pink-point) and $\mathrm{K}_{2} \mathrm{CO}_{3}$ (blue-triangle). Intensity were maximized for better comparison.

broken under the X-ray beam, which leads to new S 2 p and F $1 \mathrm{~s}$ components at lower binding energy, whose intensity increased over iterations. The XPS core spectra for KFSI in Figure 1 were obtained at the beginning of the salt degradation, so that degradation product peaks were negligible. In the case of SEI analysis of cycled electrodes, that often requires long time analysis, it could thus be impossible to identify SEI's compounds from X-ray beam degradation products. Therefore, for SEI analysis, it is recommended to perform (i) quick degradation tests using few short-time iterative scans to identify the core levels affected by a possible X-ray beam degradation (i.e. evolving peaks over iteration), (ii) full analysis on at least 2 different "fresh" areas (for reproducibility) still using short-time iterations and (iii) sum the first nonevolving iteration scans for each beam-sensitive core level.

SEI's reference compounds. Products from salt and solvent degradation (i.e. SEI compounds) are typically inorganic compounds such as $\mathrm{MF}, \mathrm{M}_{2} \mathrm{CO}_{3}$ or $\mathrm{MOH}$, and organic compounds such as $\mathrm{ROM}, \mathrm{RCO}_{2} \mathrm{M}$ or $\mathrm{ROCO}_{2} \mathrm{M}$ with $\mathrm{M}$ being $\mathrm{Li}$, $\mathrm{Na}$ or $\mathrm{K}$ and $\mathrm{R}$ being an alkyl chain. The formation of these compounds depends on experimental storage/cycling conditions, which are not discussed in this study.

Inorganic compounds. Figure 2 shows the F 1s XPS core spectra of MF compounds. Based on initial state effect in relation with the ionic charge, a binding energy shift was observed between $\mathrm{KF}, \mathrm{NaF}$ and $\mathrm{LiF}$ with peaks located at $684.2,684.8$ and $685.1 \pm 0.1 \mathrm{eV}$, respectively. Figure 3 shows the $\mathrm{C} 1 \mathrm{~s}$ and $\mathrm{O} 1 \mathrm{~s}$ XPS core spectra of $\mathrm{M}_{2} \mathrm{CO}_{3}$. compounds. On the $\mathrm{O} 1 \mathrm{~s}$ core spectra, a peak was observed at 530.4, 531.1 and $531.8 \pm 0.1 \mathrm{eV}$ attributed to $-\mathrm{CO}_{3}$ groups for $\mathrm{K}_{2} \mathrm{CO}_{3}$, $\mathrm{Na}_{2} \mathrm{CO}_{3}$ and $\mathrm{Li}_{2} \mathrm{CO}_{3}$, respectively. The corresponding $\mathrm{C} 1 \mathrm{~s}$ peak was observed at 288.6, 289.4 and $290.1 \pm 0.1 \mathrm{eV}$. The shift towards low binding energies for $\mathrm{C} 1 \mathrm{~s}$ and $\mathrm{O} 1 \mathrm{~s}$, as the alkali's atomic number increases, 


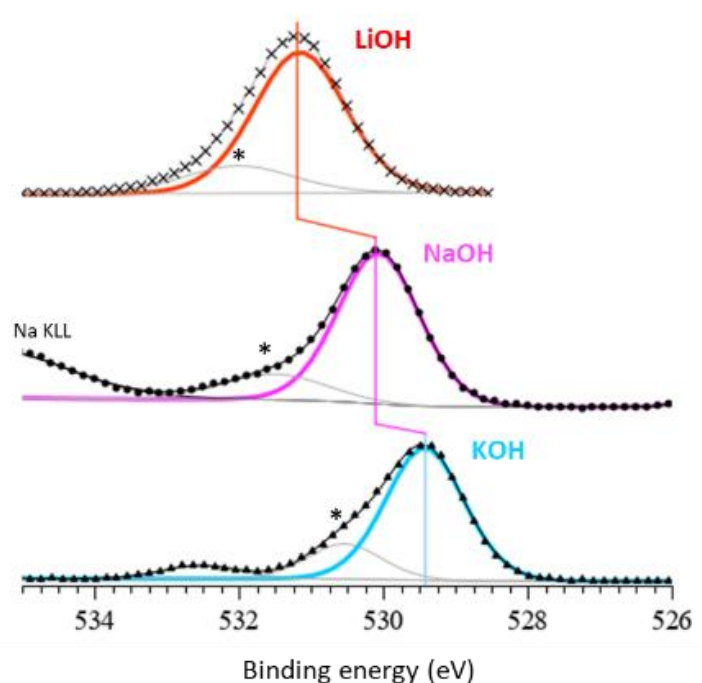

Figure 4. O 1s XPS core level spectra of LiOH (red-cross), $\mathrm{NaOH}$ (pink-point) and $\mathrm{KOH}$ (blue-triangle). Intensity were maximized for better comparison. *These peaks are attributed to $\mathrm{M}_{2} \mathrm{CO}_{3}$ impurities.

has already been reported in the literature ${ }^{21}$ and is further discussed with Figure 5.

Figure 4 shows the O 1s XPS core spectra of MOH compounds. For $\mathrm{NaOH}$ and $\mathrm{LiOH}$, peaks were observed at 529.8 $\pm 0.1 \mathrm{eV}$ and $531.1 \pm 0.1 \mathrm{eV}$, as also reported in the literature $^{12,22}$. For $\mathrm{KOH}$, the O 1s peak was observed at 529.4 $\pm 0.1 \mathrm{eV}$. Note that characteristic peaks of $\mathrm{M}_{2} \mathrm{CO}_{3}$, were identified at 288.7-530.5 $\pm 0.1 \mathrm{eV}, 289.7-531.4 \pm 0.1 \mathrm{eV}$ and $289.9 \mathrm{eV}-532.0 \pm 0.1 \mathrm{eV}$ for $\mathrm{M}$ being $\mathrm{K}, \mathrm{Na}$ and $\mathrm{Li}$, respectively. This is explained by impurities formed by the reactive surface of such $\mathrm{MOH}$ compound when stored under air (i.e. commercially). This was confirmed by exposing under air for 1 week a $\mathrm{KOH}$ pellet prepared from the $\mathrm{KOH}$ powder (initially grinded in a mortar), for which a much higher amount of $\mathrm{K}_{2} \mathrm{CO}_{3}$ was observed (Figure S2). Nevertheless, the presence of $\mathrm{K}_{2} \mathrm{CO}_{3}$ confirms that the binding energy values for $\mathrm{KOH}$ are correctly estimated to $\pm 0.1 \mathrm{eV}$.

Figure 5 shows a schematic representation of the $1^{\text {st }}$ ionization potential $\left(\mathrm{IP}_{1}\right)$ effect on the binding energy value for the alkali metals (top) as well as the binding energy evolution of $\mathrm{MF}, \mathrm{MOH}$ and $\mathrm{M}_{2} \mathrm{CO}_{3}$ XPS components as function of the first ionisation potential ( $\left.\mathrm{IP}_{1}\right)$ of the alkali metals (bottom). For all samples, XPS binding energies decreased when decreasing $\mathrm{IP}_{1}$ (i.e. from $\mathrm{Li}$ to $\mathrm{K}$ ) due to the increasing delocalisation of valence electron density (i.e. screening effect increase) from the $\mathrm{M}$ atom to the $\mathrm{F}$ atom for $\mathrm{MF}$, to the $\mathrm{O}$ atom for $\mathrm{MOH}$ and to the $\mathrm{O}$ atom for $\mathrm{M}_{2} \mathrm{CO}_{3}$, as illustrated on top of Figure 5. In the case of the $\mathrm{M}_{2} \mathrm{CO}_{3}$ compounds, this is associated with an additional delocalisation along the $\mathrm{M} \rightarrow \mathrm{O}$ bonds (i.e. it increases the negative charge of the $\mathrm{O}$ that shift the electron density to the carbon). Thus the $\mathrm{M}_{2} \mathrm{CO}_{3}$ carbon binding energy is also shifted to much lower binding energy values from $\mathrm{Li}_{2} \mathrm{CO}_{3}(290.1 \pm 0.1 \mathrm{eV})$ to $\mathrm{K}_{2} \mathrm{CO}_{3}(288.6 \pm 0.1 \mathrm{eV})$, in agreement with the literature. ${ }^{21}$ Note that the $\mathrm{C}$ atom of $\mathrm{K}_{2} \mathrm{CO}_{3}$ was thus observed at the same binding energy of typical $\mathrm{RCO}_{2} \mathrm{Li}$ compounds ${ }^{23,24}$, which clearly highlights the need of K-based reference compounds to enable reliable XPS analysis of the SEI in KIBs.

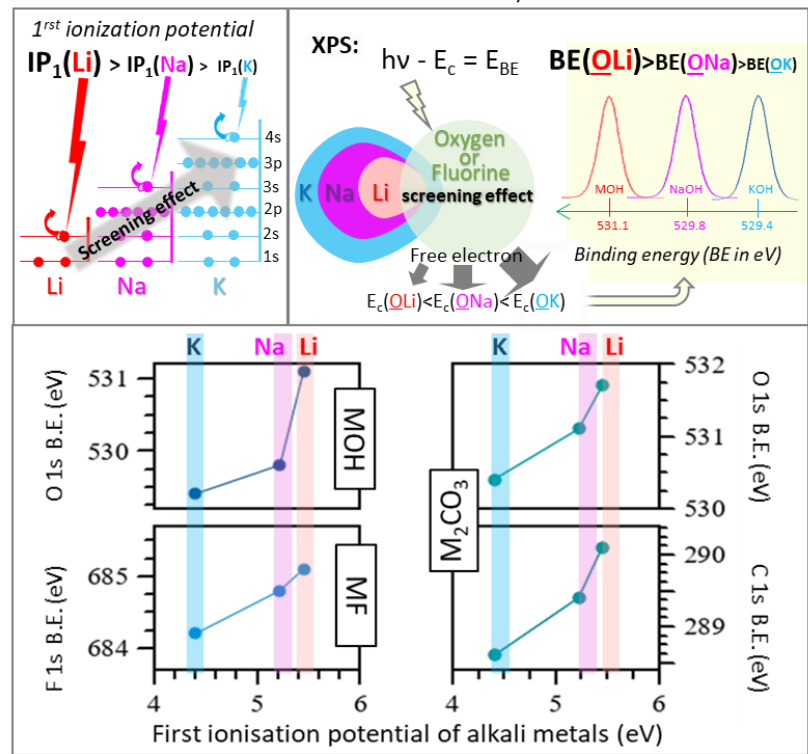

Figure 5. Schematic representation of the $1^{\text {st }}$ ionization potential effect on the binding energy value for the alkali metals (Top) as well as binding energy $(\mathrm{eV})$ evolution of $\mathrm{MF}, \mathrm{MOH}$ and $\mathrm{M}_{2} \mathrm{CO}_{3}$ XPS components as a function of the first ionization potential of alkali metals (Bottom). The binding energy values range is \pm 0.1 $\mathrm{eV}$ for all components.

Organic compounds Figure 6 shows the $\mathrm{K} 2 \mathrm{p}-\mathrm{C} 1 \mathrm{~s}$ and $\mathrm{O}$ 1s XPS core spectra of $\mathrm{CH}_{3} \mathrm{OCO}_{2} \mathrm{~K}, \mathrm{CH}_{3} \mathrm{CH}_{2} \mathrm{CO}_{2} \mathrm{~K}, \mathrm{~K}_{2} \mathrm{C}_{2} \mathrm{O}_{4}$, $\mathrm{CH}_{3} \mathrm{CH}_{2} \mathrm{OK}$ and $\mathrm{CH}_{3} \mathrm{OK}$ compounds. For $\mathrm{CH}_{3} \mathrm{OCO}_{2} \mathrm{~K}$, the $\mathrm{C}$ $1 \mathrm{~s}$ core spectrum showed two peaks with equal areas at 286.3 $\pm 0.1 \mathrm{eV}$ and $289.4 \pm 0.1 \mathrm{eV}$, attributed to the carbon in $\mathrm{CH}_{3} \mathrm{O}$ and $-\mathrm{OCO}_{2} \mathrm{~K}$ environment, respectively. The corresponding $\mathrm{O}$ 1 s spectrum showed two components with a $1 / 2$ ratio at 532.9 $\pm 0.1 \mathrm{eV}$ and $531.1 \pm 0.1 \mathrm{eV}$, attributed to the oxygen in $\mathrm{CH}_{3} \mathrm{O}$ and $-\mathrm{CO}_{2} \mathrm{~K}$. For information, the $\mathrm{CH}_{3} \mathrm{OCO}_{2} \mathrm{Li}$ counterpart showed components at $286.8 \pm 0.1 \mathrm{eV}\left(\mathrm{CH}_{3} \mathrm{O}-\right), 290.1 \pm 0.1 \mathrm{eV}$ $\left(-\mathrm{OCO}_{2} \mathrm{~K}\right), 533.3 \pm 0.1 \mathrm{eV}\left(\mathrm{CH}_{3} \mathrm{O}-\right)$ and $531.8 \pm 0.1 \mathrm{eV}(-$ $\left.\mathrm{CO}_{2} \mathrm{Li}\right)^{13,23,24}$. Therefore, the $\mathrm{K}$ compound leads to lower binding energy ( $-0.5 \mathrm{eV}$ on average) compared to the $\mathrm{Li}$ one, highlighting the effect of the lower ionization potential of K. Note that additional peaks (marked by an $*$ in Figure 6) were observed at $288.0 \pm 0.1 \mathrm{eV}$ and $531.1 \pm 0.1 \mathrm{eV}$ (this latter is based on XPS quantification), attributed to a $-\mathrm{CO}_{2} \mathrm{~K}$ compound impurities such as $\mathrm{K}_{2} \mathrm{C}_{2} \mathrm{O}_{4}$ or $\mathrm{RCO}_{2} \mathrm{~K}$. The peak at $529.4 \pm 0.1$ $\mathrm{eV}$ is attributed to $\mathrm{KOH}$ impurities. Both $\mathrm{K}_{2} \mathrm{C}_{2} \mathrm{O}_{4} / \mathrm{RCO}_{2} \mathrm{~K}$ and $\mathrm{KOH}$ impurities are due to the absence of purification after the synthesis process of this compound. However, the growth of these additional peaks during acquisition while the $\mathrm{CH}_{3} \mathrm{OCO}_{2} \mathrm{~K}$ peaks decreased suggests that these impurities are also degradation products under the $\mathrm{X}$-ray beam (Figure S3).

The $\mathrm{C} 1 \mathrm{~s}$ XPS core spectra of $\mathrm{CH}_{3} \mathrm{CH}_{2} \mathrm{CO}_{2} \mathrm{~K}$ and $\mathrm{K}_{2} \mathrm{C}_{2} \mathrm{O}_{4}$ show one peak at $288.1 \pm 0.1 \mathrm{eV}$, attributed to a carbon in $\mathrm{CO}_{2} \mathrm{~K}$ environment, while the corresponding $\mathrm{O}$ 1s peak was observed at $531.1 \pm 0.1 \mathrm{eV}$. Note that no binding energy difference was thus observed between oxygen in a $-\mathrm{CO}_{2} \mathrm{~K}$ environment $\left(\mathrm{CH}_{3} \mathrm{CH}_{2} \mathrm{CO}_{2} \mathrm{~K} / \mathrm{K}_{2} \mathrm{C}_{2} \mathrm{O}_{4}\right)$ and oxygen in a $-\mathrm{OCO}_{2} \mathrm{~K}$ environment $\left(\mathrm{CH}_{3} \mathrm{OCO}_{2} \mathrm{~K}\right)$. The $\mathrm{C} 1 \mathrm{~s}$ XPS core spectra of $\mathrm{CH}_{3} \mathrm{OK}$ and $\mathrm{CH}_{3} \mathrm{CH}_{2} \mathrm{OK}$ show one peak at $286.1 \pm 0.1 \mathrm{eV}$ attributed to carbon in - $\mathrm{COK}$ environment while corresponding $\mathrm{O} 1 \mathrm{~s}$ peak was observed at $531.3 \pm 0.1 \mathrm{eV}$. Note that for 
both $\mathrm{CH}_{3} \mathrm{OK}$ and $\mathrm{CH}_{3} \mathrm{CH}_{2} \mathrm{OK}$, the presence of $\mathrm{K}_{2} \mathrm{CO}_{3}$ was observed as it is used as stabilizer for these commercial compounds. Note also the presence of $\mathrm{KOH}$ impurity. Note that a slight $\mathrm{O} 1 \mathrm{~s}$ binding energy difference (about $0.4 \mathrm{eV}$ ) was observed between the $-\mathrm{COK}$ and $-\mathrm{CO}_{2} \mathrm{~K} /-\mathrm{OCO}_{2} \mathrm{~K}$ environments. It is thus proposed that for SEI analysis, a single $\mathrm{O} 1 \mathrm{~s}$ component (with a larger FWHM) could be used to represent these different environments. Finally, note that for $\mathrm{CH}_{3} \mathrm{CH}_{2} \mathrm{CO}_{2} \mathrm{~K}$ and $\mathrm{CH}_{3} \mathrm{CH}_{2} \mathrm{OK}$, the $\mathrm{CH}_{\mathrm{x}}$ environment was observed at $285.0 \pm 0.1 \mathrm{eV}$ with good correlation with the expected atomic percentage (see Table S2).

As previously mentioned, for XPS analysis of SEI in KIB, one should not rely on LiBs literature for peak assignment. Moreover, to avoid calibration method issue and/or charging effect between studies, the relative binding energies or $\triangle \mathrm{BE}$, i.e. the binding energy difference between core level components (Table S3) can be used in addition to the absolute binding energies (Table S2) so that more reliable SEI analysis can be obtain. Figure 7 thus summarizes the relative (red-written labels) and absolute (values read on axes) binding energies for the KIBs electrolyte salts (in yellow) and the K-based reference compounds (organic in blue and inorganic in orange) as obtained in this work. Commonly used electrode additives (binders and carbon black) have also been reported for information (grey-color), based on previous work. ${ }^{23,25}$ 


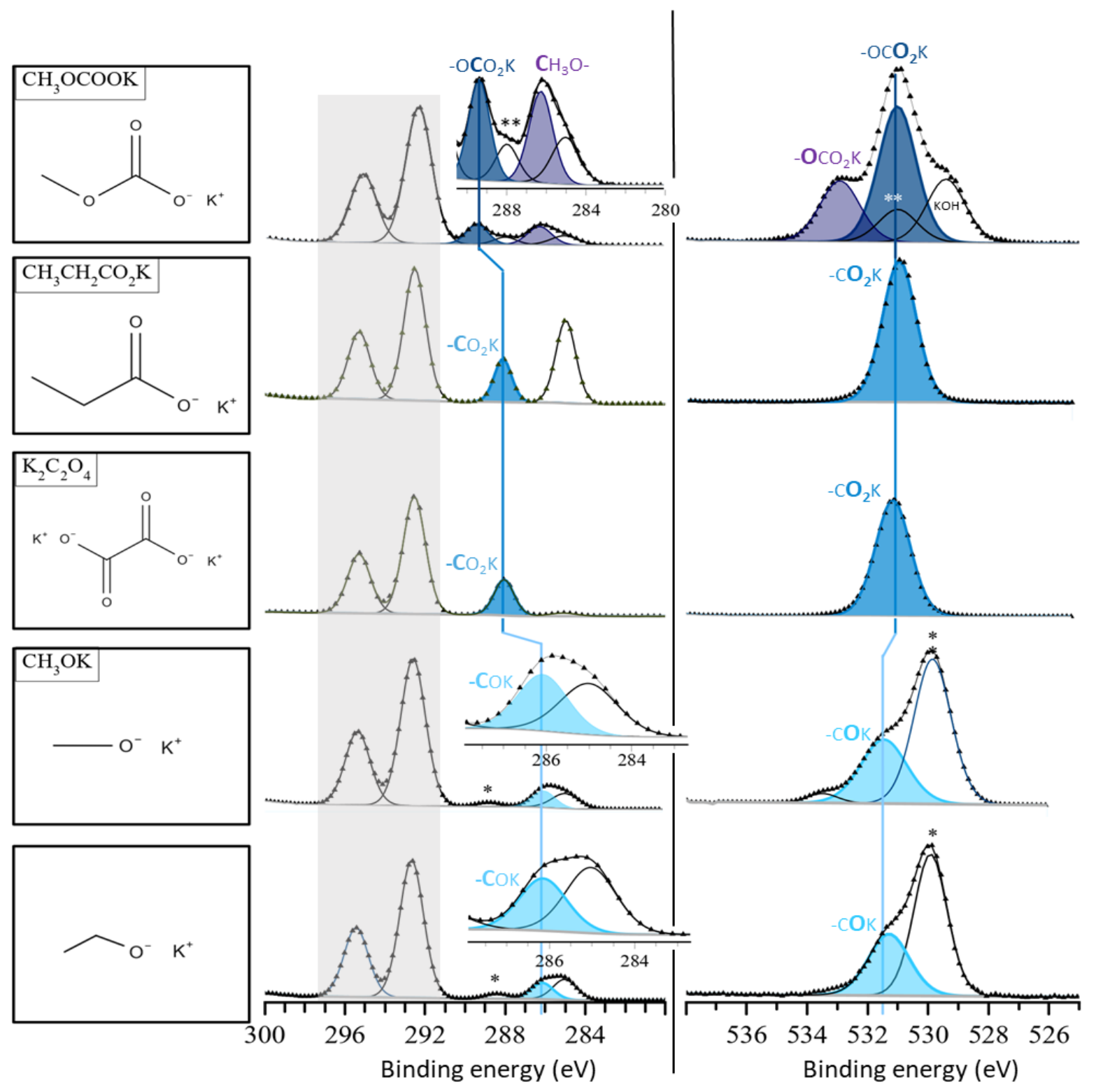

Figure 6. $\mathrm{K} 2 \mathrm{p}-\mathrm{C}$ 1s (left) and $\mathrm{O}$ 1s (right) XPS core level spectra for $\mathrm{CH}_{3} \mathrm{OCO}_{2} \mathrm{~K}, \mathrm{CH}_{3} \mathrm{CH}_{2} \mathrm{CO}_{2} \mathrm{~K}, \mathrm{~K}_{2} \mathrm{C}_{2} \mathrm{O}_{4}, \mathrm{CH}_{3} \mathrm{CH}_{2} \mathrm{OK}$, and $\mathrm{CH}_{3} \mathrm{OK}$ compounds. For $\mathrm{CH}_{3} \mathrm{CH}_{2} \mathrm{OK}$, and $\mathrm{CH}_{3} \mathrm{OK}, \mathrm{K}_{2} \mathrm{CO}_{3}$ was also observed (*) as it is used as stabilizer. For $\mathrm{CH}_{3} \mathrm{OCO} \mathrm{K}-\mathrm{CO}_{2} \mathrm{~K}$ impurities was observed (**) in addition to $\mathrm{KOH}$.

\section{CONCLUSIONS}

$\mathrm{K}$-ion batteries (KIBs) performance are governed by the electrolyte reactivity, i.e. by the SEI formation from the salts and solvents degradation during storage/cycling. XPS analysis of the SEI is thus of great importance but remained based on Li-ion and Na-ion literature so far. Therefore, the present work provides a rather complete XPS database of commercial Kbased reference compounds. The effect of the much lower first ionization potential of $\mathrm{K}$ compared to $\mathrm{Na}$ and $\mathrm{Li}$ was clearly observed for the inorganic compounds $\mathrm{M}_{2} \mathrm{CO}_{3}, \mathrm{MF}$ and $\mathrm{MOH}$ ( $\mathrm{M}=\mathrm{Li}, \mathrm{Na}$ or $\mathrm{K}$ ) compounds. For instance, the $\mathrm{C} 1 \mathrm{~s}$ peak of $\mathrm{K}_{2} \mathrm{CO}_{3}$ was observed $288.6 \pm 0.1 \mathrm{eV}$ compared to 289.4 and $290.1 \pm 0.1 \mathrm{eV}$ for $\mathrm{Na}_{2} \mathrm{CO}_{3}$ and $\mathrm{Li}_{2} \mathrm{CO}_{3}$, respectively. Note that such very low binding energy value for the $\mathrm{C} 1 \mathrm{~s}$ peak of $\mathrm{K}_{2} \mathrm{CO}_{3}$ is typical of the $\mathrm{C} 1 \mathrm{~s}$ peak for $\mathrm{RCO}_{2} \mathrm{Li}$ compounds. Analysis of organic K-based compounds such as ROCOOK, $\mathrm{RCO}_{2} \mathrm{~K}$ and $\mathrm{ROK}$ is also provided for the first time. This work also provides relative binding energy values, $\triangle \mathrm{BE}$, i.e. the binding energy difference between core level components in addition to the absolute binding energies to further help the analysis of SEI. Overall, this work will thus help researchers to get reliable SEI interpretation in KIBs, which should lead to a better understanding / improving of KIBs cells performance and lifetime. 


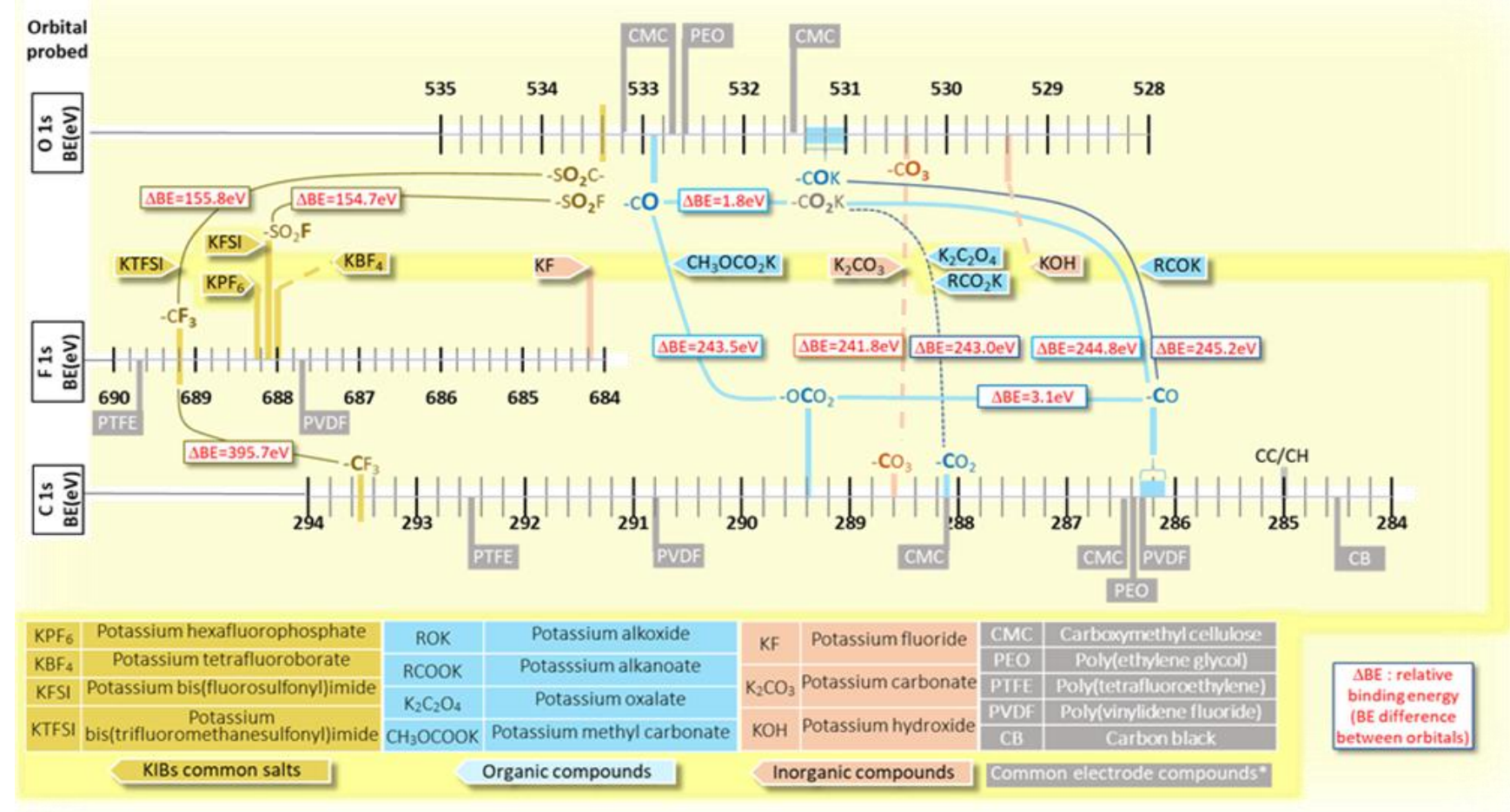

Figure 7. O 1s (top axe), F 1s (middle axe) and C 1s (bottom axe) absolute binding energy (eV) of KIBs electrolyte salts (in yellow-color), K-based reference compounds (organic in blue-color and inorganic in orange-color) and commonly used electrode additives (binders and carbon black, grey-color, as reported in literature). For KIBs SEI's compounds and KIBs common salts, relative binding energy between represented orbitals are also given in red-written labels.

\section{ASSOCIATED CONTENT}

\section{Supporting Information}

The Supporting Information is available free of charge on the ACS Publications website.

Tables including supplier name and purity grade of the reference powder samples analyzed in this work; binding energy and experimental/theoretical atomic percentage for the $\mathrm{M}$ based reference compounds $(\mathrm{M}=\mathrm{K}$ or $\mathrm{Li})$; relative binding energies $\triangle \mathrm{BE}$ for $\mathrm{M}$-based reference compounds. XPS core level spectra figures including M-based salts; a $\mathrm{K}_{2} \mathrm{CO}_{3}-\mathrm{KOH}$ sample; $\mathrm{CH}_{3} \mathrm{OCO}_{2} \mathrm{~K}$ XPS core spectra evolution under the Xray beam.

\section{AUTHOR INFORMATION}

\section{Corresponding Author}

* Lénaïc Madec - Universite de Pau et des Pays de l'Adour, E2S UPPA, Institut des Sciences Analytiques et de Physicochimie pour l'Environnement et les Matériaux/CNRS, UMR5254, 64000, Pau, France ; Réseau sur le Stockage Electrochimique de l'Energie (RS2E), CNRS FR3459, 33 Rue Saint Leu, 80039 Amiens Cedex, France ; Email : lenaic.madec@univ-pau.fr Hervé Martinez - Universite de Pau et des Pays de l'Adour, E2S UPPA, Institut des Sciences Analytiques et de Physicochimie pour l'Environnement et les Matériaux/CNRS, UMR5254, 64000, Pau, France ; Réseau sur le Stockage Electrochimique de l'Energie (RS2E), CNRS FR3459, 33 Rue Saint Leu, 80039 Amiens Cedex, France ; Email : herve.martinez@univ-pau.fr

\section{Author}

Laure Caracciolo - Universite de Pau et des Pays de l'Adour, E2S UPPA, Institut des Sciences Analytiques et de Physicochimie pour l'Environnement et les Matériaux/CNRS, UMR5254, 64000, Pau, France

\section{Author Contributions}

All authors have given approval to the final version of the manuscript.

\section{Notes}

The authors declare no competing financial interest.

\section{ACKNOWLEDGMENT}

\section{Acknowledgments}

The project leading to this publication has received funding from Excellence Initiative of Université de Pau et des Pays de l'Adour - I-Site E2S UPPA, a French "Investissements d'Avenir" programme.

\section{REFERENCES}

(1) Zou, X.; Xiong, P.; Zhao, J.; Hu, J.; Liu, Z.; Xu, Y. Recent Research Progress in Non-Aqueous Potassium-Ion Batteries. Phys. Chem. Chem. Phys. 2017, 19 (39), 26495-26506. 
https://doi.org/10.1039/c7cp03852f.

Wang, H.; Zhai, D.; Kang, F. Solid Electrolyte Interphase (SEI)

in Potassium Ion Batteries. Energy Environ. Sci. 2020, 13 (12),

4583-4608. https://doi.org/10.1039/d0ee01638a.

Hosaka, T.; Kubota, K.; Hameed, A. S.; Komaba, S. Research Development on K-Ion Batteries. Chem. Rev. 2020, 120 (14), 6358-6466. https://doi.org/10.1021/acs.chemrev.9b00463.

Wang, B.; Peng, Y.; Yuan, F.; Liu, Q.; Sun, L.; Zhang, P.; Wang, Q.; Li, Z.; Wu, Y. A. A Comprehensive Review of Carbons Anode for Potassium-Ion Battery: Fast Kinetic, Structure Stability and Electrochemical. J. Power Sources 2021, $484 \quad$ (November 2020), 229244. https://doi.org/10.1016/j.jpowsour.2020.229244.

(5) Wu, Y.; Zhao, H.; Wu, Z.; Yue, L.; Liang, J.; Liu, Q.; Luo, Y.; Gao, S.; Lu, S.; Chen, G.; Shi, X.; Zhong, B.; Guo, X.; Sun, X. Rational Design of Carbon Materials as Anodes for PotassiumIon Batteries. Energy Storage Mater. 2021, 34 (October 2020), 483-507. https://doi.org/10.1016/j.ensm.2020.10.015.

Wu, Z.; Zou, J.; Chen, S.; Niu, X.; Liu, J.; Wang, L. PotassiumIon Battery Cathodes: Past, Present, and Prospects. J. Power Sources 2021, 484 (November 2020), 229307. https://doi.org/10.1016/j.jpowsour.2020.229307.

Liao, J.; Hu, Q.; He, X.; Mu, J.; Wang, J.; Chen, C. A Long Lifespan Potassium-Ion Full Battery Based on KVPO4F Cathode and VPO4 Anode. J. Power Sources 2020, 451, 227739. https://doi.org/10.1016/j.jpowsour.2020.227739.

Kim, H.; Tian, Y.; Ceder, G. Origin of Capacity Degradation of High-Voltage KVPO 4 F Cathode . J. Electrochem. Soc. 2020, 167 (11), 110555. https://doi.org/10.1149/1945-7111/aba54e.

Caracciolo, L.; Madec, L.; Petit, E.; Gabaudan, V.; Carlier, D.; Croguennec, L.; Martinez, H. Electrochemical Redox Processes Involved in Carbon-Coated KVPO $4 \mathrm{~F}$ for High Voltage K-Ion Batteries Revealed by XPS Analysis . J. Electrochem. Soc. 2020, 167 (13), 130527. https://doi.org/10.1149/19457111/abbb0c.

(10) Madec, L.; Ellis, L. D. Exploring Interactions between Electrodes in $\mathrm{Li}[\mathrm{Ni}$ x $\mathrm{Mn}$ y Co 1-Xy ]O 2 /Graphite Cells through Electrode/Electrolyte Interfaces Analysis . $J$.
Electrochem. Soc. $\quad \mathbf{2 0 1 7}, 164 \quad$ (14), A3718-A3726. https://doi.org/10.1149/2.1011714jes.

Madec, L.; Gabaudan, V.; Gachot, G.; Stievano, L.; Monconduit, L.; Martinez, H. Paving the Way for K-Ion Batteries: Role of Electrolyte Reactivity through the Example of Sb-Based Electrodes. ACS Appl. Mater. Interfaces 2018, 10, 34116-34122. https://doi.org/10.1021/acsami.8b08902.

Wooda, K. N.; Teetera, G. XPS on Li Battery Related Compounds: Analysis of Inorganic Sei Phases and a Methodology for Charge Correction. arXiv 2018, 1-33.

Dedryvère, R.; Gireaud, L.; Grugeon, S.; Laruelle, S.; Tarascon, J. M.; Gonbeau, D. Characterization of Lithium Alkyl Carbonates by X-Ray Photoelectron Spectroscopy: Experimental and Theoretical Study. J. Phys. Chem. B 2005, 109 (33), 15868-15875. https://doi.org/10.1021/jp051626k.

(14) Fingerle, M.; Späth, T.; Schulz, N.; Hausbrand, R. Adsorption of Ethylene Carbonate on Lithium Cobalt Oxide Thin Films: A Synchrotron-Based Spectroscopic Study of the Surface Chemistry. Chem. Phys. 2017, 498-499, 19-24. https://doi.org/10.1016/j.chemphys.2017.09.004.

Leroy, S.; Martinez, H.; Dedryvère, R.; Lemordant, D.; Gonbeau, D. Influence of the Lithium Salt Nature over the Surface Film Formation on a Graphite Electrode in Li-Ion Batteries: An XPS Study. Appl. Surf. Sci. 2007, 253 (11), 48954905. https://doi.org/10.1016/j.apsusc.2006.10.071.

Greczynski, G.; Hultman, L. X-Ray Photoelectron Spectroscopy: Towards Reliable Binding Energy Referencing. Prog. Mater. Sci. 2020, 107 (June 2018), 100591. https://doi.org/10.1016/j.pmatsci.2019.100591.

Engelhard, M. H.; Baer, D. R.; Herrera-Gomez, A.; Sherwood, P. M. A. Introductory Guide to Backgrounds in XPS Spectra and Their Impact on Determining Peak Intensities. J. Vac. Sci. $\begin{array}{llllll}\text { Technol. } & A & \mathbf{2 0 2 0}, & 38 & \text { (6), } & 063203 .\end{array}$ https://doi.org/10.1116/6.0000359.

(18) Hosaka, T.; Kubota, K.; Hameed, A. S.; Komaba, S. Research Development on K-Ion Batteries. Chem. Rev. 2020, 120 (14), 6358-6466. https://doi.org/10.1021/acs.chemrev.9b00463.

Il'Inchik, E. A. Standards for X-Ray Photoelectron 
Spectroscopy of Boron Compounds. J. Appl. Spectrosc. 2008 ,

75 (6), 883-891. https://doi.org/10.1007/s10812-009-9116-z.

(20)

Shkrob, I. A.; Marin, T. W.; Zhu, Y.; Abraham, D. P. Why

Bis(Fluorosulfonyl)Imide Is a "Magic Anion" for

Electrochemistry. J. Phys. Chem. C 2014, 118 (34), 1966119671. https://doi.org/10.1021/jp506567p.

(21)

Shchukarev, A. V.; Korolkov, D. V. XPS Study of Group IA

Carbonates. Cent. Eur. J. Chem. 2004, 2 (2), 347-362. https://doi.org/10.2478/BF02475578.

(22)

Dupin, J. C.; Gonbeau, D.; Vinatier, P.; Levasseur, A. Systematic XPS Studies of Metal Oxides, Hydroxides and Peroxides. Phys. Chem. Chem. Phys. 2000, 2 (6), 1319-1324. https://doi.org/10.1039/a908800h.

(23) Gieu, J.-B.; Courrèges, C.; Ouatani, L. El; Tessier, C.; Martinez, H. Influence of Vinylene Carbonate Additive on the Li 4 Ti $5 \mathrm{O}$ 12 Electrode/Electrolyte Interface for Lithium-Ion Batteries . $J$. Electrochem. Soc. 2017, 164 (6), A1314-A1320. https://doi.org/10.1149/2.0111707jes.

(24) Gieu, J. B.; Courrèges, C.; El Ouatani, L.; Tessier, C.; Martinez, H. Temperature Effects on Li4Ti5O12 Electrode/Electrolyte Interfaces at the First Cycle: A X-Ray Photoelectron Spectroscopy and Scanning Auger Microscopy Study. J. Power Sources $\quad$ 2016, 318, 291-301. https://doi.org/10.1016/j.jpowsour.2016.04.007.
Girardeaux, C.; Pireaux, J.-J. Analysis of Poly(Tetrafluoroethylene) (PTFE) by XPS. Surf. Sci. Spectra 1996, 4 (2), 138-141. https://doi.org/10.1116/1.1247814.

Chang, L. S.; Wu, H. C.; Lin, Y. C.; Su, C. Y.; Pan, J. P. XPS Study on the STOBA Coverage on $\mathrm{Li}(\mathrm{NiO} .4 \mathrm{Co} 0.2 \mathrm{Mn} 0.4) \mathrm{O} 2$ Oxide in Pristine Electrodes. Surf. Interface Anal. 2017, 49 (10), 1017-1022. https://doi.org/10.1002/sia.6267.

Zhang, F.; Dou, J.; Zhang, H. Mixed Membranes Comprising Carboxymethyl Cellulose (as Capping Agent and Gas Barrier Matrix) and Nanoporous ZIF-L Nanosheets for Gas Separation Applications. Polymers (Basel). 2018, $10 \quad$ (12). https://doi.org/10.3390/polym10121340.

Gieu, J. B.; Winkler, V.; Courrèges, C.; El Ouatani, L.; Tessier, C.; Martinez, H. New Insights into the Characterization of the Electrode/Electrolyte Interfaces within LiMn2O4/Li4Ti5O12 Cells, by X-Ray Photoelectron Spectroscopy, Scanning Auger Microscopy and Time-of-Flight Secondary Ion Mass Spectrometry. J. Mater. Chem. A 2017, 5 (29), 15315-15325. https://doi.org/10.1039/c7ta02529g. Louette, P.; Bodino, F.; Pireaux, J.-J. Poly(Ethylene Oxide) (PEO) XPS Reference Core Level and Energy Loss Spectra. Surf. Sci. Spectra 2005, $12 \quad$ (1), 59-63. https://doi.org/10.1116/11.20050912. 